\title{
Scanning electron microscopic studies on pollen from honey. IV. Surface pattern of pollen of Sapium sebiferum and Euphorbia spp (Euphorbiaceae) *
}

\author{
JH Dustmann, K von der Ohe \\ Niedersächsisches Landesinstitut für Bienenkunde, Wehlstraße 4a, D-3100 Celle, Germany
}

(Received 19 March 1992; accepted 14 October 1992)

\begin{abstract}
Summary - Several species of Euphorbia and Sapium plants produce considerable amounts of nectar, which is collected by bees for honey production. In order to identify the nectar source species we used the usual method of melissopalynology (identification of polien grains by light microscopy) as well as scanning electron microscopic (SEM) studies. Authenticated specimens of pollen were examined in a state of contraction as well as expansion. Four types of exine surface pattern could be distinguished by SEM. E Cœrulescens, E ledienii and $E$ tetragona show the same 3 variations in exine structure (type A, B, C). It was therefore not possible to distinguish between these 3 Euphorbia species. However Sapium sebiferum showed a specific pattern and uniformity of exine structure (type D).
\end{abstract}

pollen / honey / Euphorbiaceae / light microscopy / scanning electron microscopy (SEM)

\section{INTRODUCTION}

The family Euphorbiaceae is one of the largest in the worlk, comprising $>300$ genera (Heywood, 1982). Pollen of some genera gathered by honeybees are wellknown in melissopalynology and enable the botanical origin of honey specimen to be identified. For example, it is possible to identify pollen of different species of Euphorbiaceae such as Croton, Euphorbia or Ricinus in honeys from different countries (Zander, 1941). The existence of special honey sources with a large amount of nectar from Euphorbia species led us to investigate the possibility of identifying pollen of different species within the genus Euphorbia. These honeys are commonly known as 'noors-honeys', which can cause acute burning in the mouth and throat (Sosath et al, 1988). In addition we wished to determine pollen characters via

\footnotetext{
* These studies constitute part of a comprehensive research program led by E Hecker, Krebsforschungszentrum Heidelberg on several Euphorbiaceae.
} 
examination of pollen grains that would distinguish Euphorbia honey from that of Sapium sebiferum (Euphorbiaceae). Microscopy (LM) as well as scanning electron microscopy (SEM) was therefore used. The melissopalynological study of the Euphorbia honeys was uninformative because of the naturally low content of Euphorbia pollen grains. Nevertheless these honeys contained high amounts of Euphorbia nectar, as confirmed by sensory test and bee botanical observations. Low pollen content is well-known for some other honey sources such as those of lime tree (Tiliaceae) and false acacia (Leguminosae) (Zander, 1935; Louveaux et al, 1970, 1978). Based on these facts, we examined authentic specimens of pollen gathered in South Africa (Euphorbia) and Louisiana, USA (Sapium). To compare complete the results of the LM and SEM examination we used Method I of Dustmann and Bote (1985) to obtain specimens from similar honey of expanded pollen grains for SEM study thus providing a possibility to transfer our results directly to melissopalynology.

\section{MATERIALS AND METHODS}

The Krebsforschungszentrum Heidelberg obtained the following authenticated pollen samples: 1) Euphorbia coerulescens: Jansenville / Caroo, South Africa, 1980; 2) Euphorbia ledienii: Kleinpoort / Caroo, South Africa, 1980; 3) Euphorbia tetragona: Keiskama Valley, South Africa, 1980; 4) Sapium sebiferum: Louisiana, USA, 1982.

After degreasing in ether, pollen grains were prepared for LM and SEM examination. The common palynological method of embedding in glycerine jelly (Erdtman, 1952) was used for LM. Pollen grains were prepared in 2 ways for SEM: 1) contracted pollen was directly dusted onto aluminium stubs provided with doublesided tape, then coated with a $20-\mathrm{nm}$ gold layer; 2) for the expanded condition at onset of germination, ie the same condition and shape found in the LM glycerine jelly preparations, pollen grains were transferred into filtered honey for $48 \mathrm{~h}$ at $35^{\circ} \mathrm{C}$. After using Method I of Dustmann and Bote (1985) - transfer to a wire screen, removal of 'pollenkitt' by ultrasonics, dehydration in acetone and a graded ethanol series, critical point drying (CPD) - pollen was dusted onto an aluminum stub provided with double-sided tape, and coated with a $20-\mathrm{nm}$ gold layer. All SEM specimens were examined at an acceleration voltage of $10 \mathrm{kV}$.

The following equipment was used: PhotoMicroscope III (Zeiss); SEM ISI-Super-II; Sputter-Coater ISI PS-2; Critical Point Drying Apparatus E 3000 (Polaron). Nomenclature for descriptions was according to Faegri and Iversen (1964).

\section{RESULTS}

\section{LM examination}

Expanded pollen grains of Euphorbia coerulescens, $E$ tetragona and Sapium sebiferum are tricolporate and characterized by the same spherical shape (equatorial view). The ectexine includes the foot layer, columellae and a perforate tectum. The grains lack any supratectal sculpturing. Size varied from $32.5-42.5 \mu \mathrm{m}$ within each species. In all pollen grains the characteristic contour of the living cell could be observed forming a yard around the pores which depended on intine thickness, and seen in polar view (fig 1).

\section{SEM examination}

Contracted pollen grains examined of the genera Euphorbia and Sapium were visible only in equatorial view depending on their prolate-oval shape. Differences in size and shape were non-significant. The characteristic margo along every colpus was hardly visible as the germination furrows were closed. Parts of the exine or single pertora- 

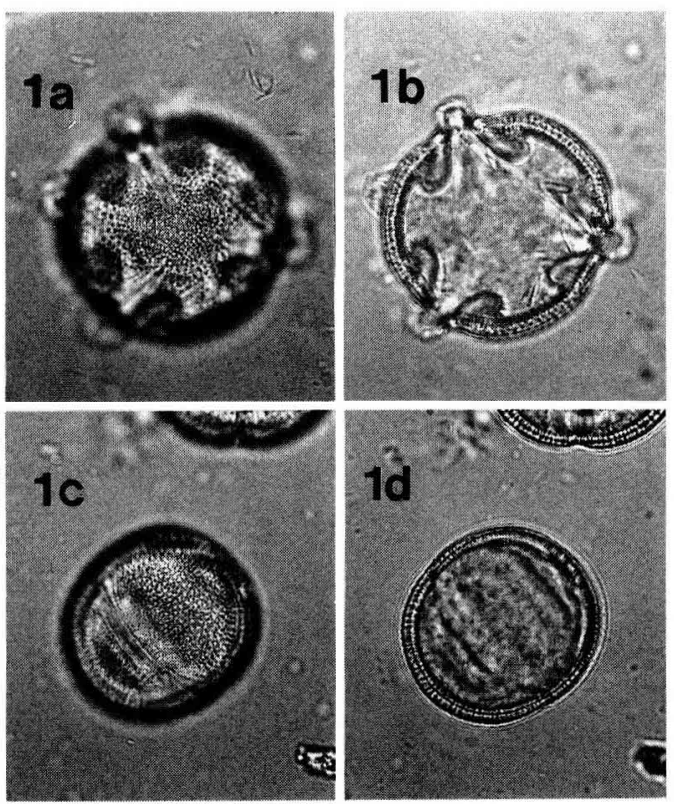

Fig 1. $L M$, pollen grain of Euphorbia species. a, b: polar view, high focus and cross-section; note the characteristic contour of the living cell. c, d: equatorial view, high focus and cross-section (magnification $\times$ 787.5).

tions (luminae) of the tectum were covered with 'pollen kitt'.

Expanded pollen grains of all specimens allowed a more detailed study in the polar as well as in the equatorial view. In $E$ coerulescens, $E$ ledienii and $E$ tetragona we found the same 3 variations in exine pattern, designated as type A, B and C. Only Sapium sebiferum showed uniformity in pollen exine pattern, which as it differed from type $A, B$ and $C$ was termed type $D$.

\section{Description of pollen exine pattern in the different types}

All pollen types are tricolporate; colpi are surrounded by a smooth, wide margo, flat- tened straight to the colpus margin, the apertural endexine shows a verrucate pattern; the exine structure is tectate-perforate.

\section{Type A}

The exine pattern is regular tectateperforate, the luminae are small and circular. The diameter is frequently smaller (up to $0.2 \mu \mathrm{m}$ ) than the width of the muri (up to $0.7 \mu \mathrm{m})$. The muri are plain or slightly vaulted (figs $2 a, b ; 3 a, b$ )

\section{Type B}

The exine pattern is regular tectateperforate. The luminae vary in size (up to $0.7 \mu \mathrm{m}$ ) and shape (circular to oval). The muri are vaulted, with a width $\leq$ diameter of the luminae. The tectum pattern mainly at the intercolpium is partially striatereticulate (figs $2 c, d ; 3 d, c$ ).

\section{Type C}

The exine pattern is irregular tectateperforate. Most of the luminae are small $(=0.2 \mu \mathrm{m})$, with irregular sometimes elongated dimensions this possibly being determined by compressed and partially incomplete muri. The width of the high vaulted muri measures up to $0.7 \mu \mathrm{m}$ (figs $2 e, f ; 3 e, f)$.

\section{Type D}

The exine pattern is regular tectateperforate characterized by small luminae (diameter $\approx 0.2 \mu \mathrm{m}$ ). The muri are wide (up to $1.2 \mu \mathrm{m}$ ) and generally plain (figs $2 \mathrm{~g}, \mathrm{~h}$; $3 g, h)$. 

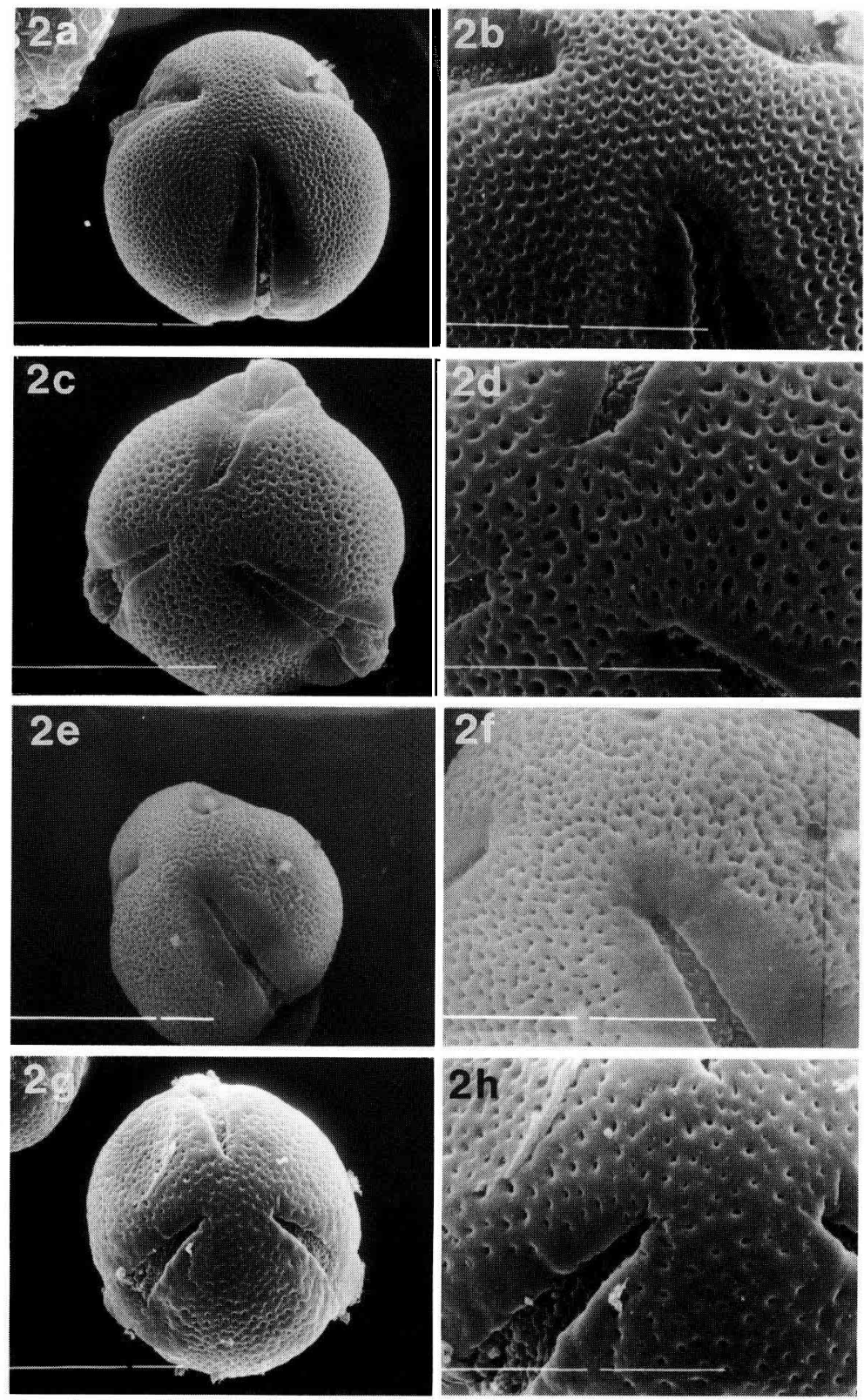

Fig 2. SEM, structure pattern types of expanded pollen grains of Euphorbia species and Sapium sebiferum as seen in polar view. a, b: type A (Euphorbia sp); c, d: type B (Euphorbia sp); e, f: type C (Euphorbia sp); g, h : type D (Sapium sebiferum) (short marker $=5 \mu \mathrm{m}$ ). 

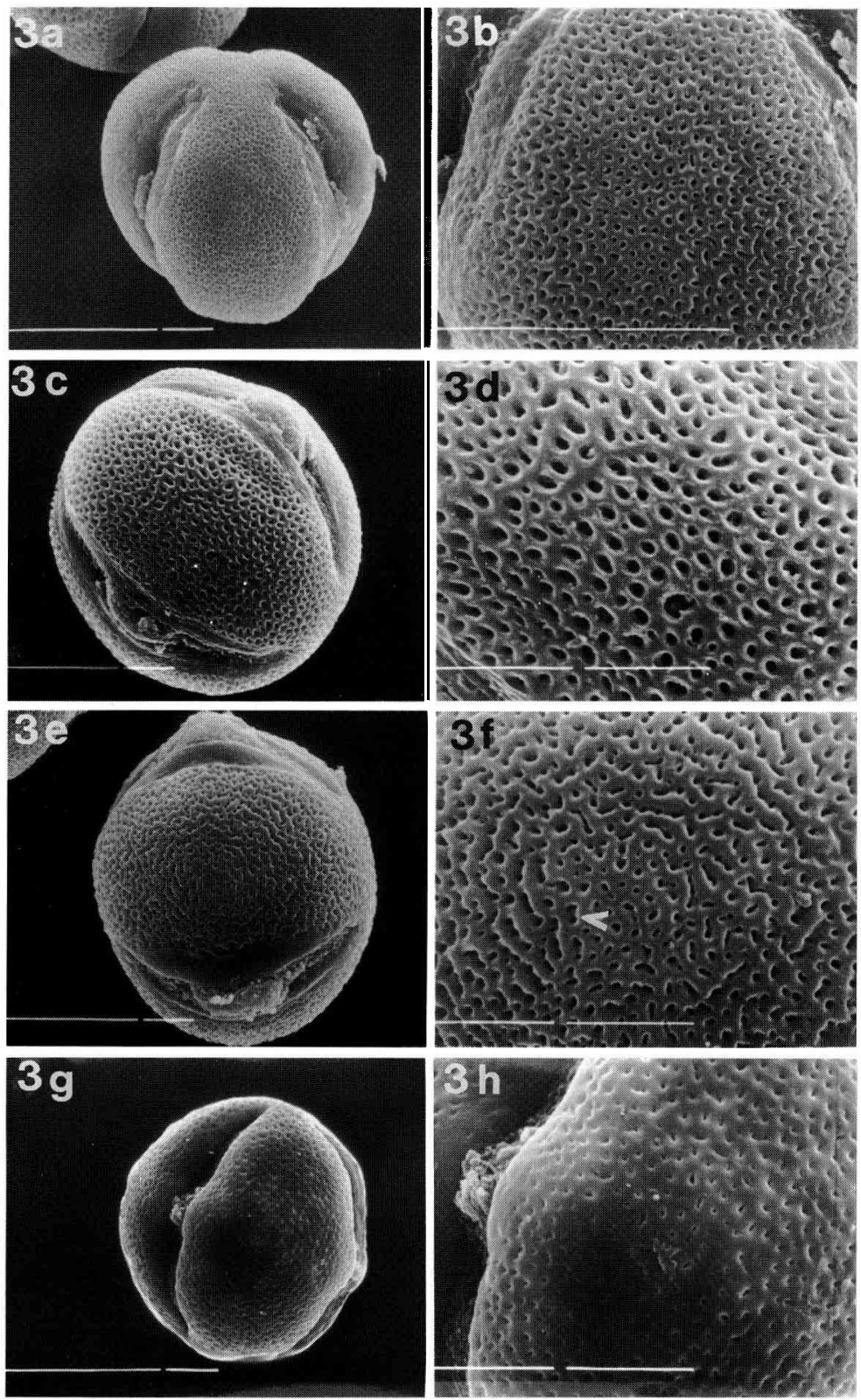

Fig 3. SEM, structure pattern types of expanded pollen grains of Euphorbia species and Sapium sebiferum as seen in equatorial view. a, b: type A (Euphorbia sp); c, d: type B (Euphorbia sp); e, f: type $\mathrm{C}$ (Euphorbia sp); g, h: type D (Sapium sebiferum) (short marker $=5 \mu \mathrm{m}$ ). 


\section{DISCUSSION}

Pollen grains of Euphorbia coerulescens, $E$ ledienii, $E$ tetragona and Sapium sebiferum exhibit similarities in size, overall shape and exine structural pattern. Using LM we were able to determine shape, construction of the exine and contour of the living cell. As volume of pollen grains changes in particular and possibly also shape and surface pattern hydration of the plasm (Blackmore and Barnes, 1985; Dustmann and Bote, 1987; von der Ohe and Dustmann, 1990) size cannot be a criterion in determining specific differences. The study of structural pattern of the ectexine was not satisfactory due to the limited depth of focus of the LM. SEM studies were carried out without acetolysis, a method already used in identifying ultrastructures in the pollen surface of apple varieties (Dustmann and Bote, 1987; von der Ohe, 1991).

Besides this, the acetolysis method (Erdmann, 1960) causes damage and loss of single pollen grains. This would not allow the SEM method to be used for Euphorbiceae honey, which shows an extreme under-representation of pollen.

The differences in structural pattern formed by a perforate tectum observed via SEM do not allow differentiation of the 3 Euphorbia species. Although 3 structural pattern types (type A, B and C) were recognized, a reference to any species is not possible: all 3 types were found in each specimen of Euphorbia coerulescens, Eledienii and $E$ tetragona. The pattern differs in shape and diameter of the luminae, which are sometimes elongated and formed by incomplete muri, as well as in the width and height of the muri. As all pollen grains were prepared in the same manner, we conclude that this variation is characteristic of these species of Euphorbia. In comparison, pollen of Sapi- um sebiferum exhibited only 1 type of characteristic tectate pattern, type $D$, which was not found in any of the Euphorbia species.

The results of the present study show that there are no microscopic characters that distinguish pollen grains of the 3 species of Euphorbia via analysis of the exine structural pattern. However, it is quite possible to find specific identifying marks in different general of Euphorbiaceae via SEM.

\section{ACKNOWLEDGMENTS}

We are very grateful to $E$ Hecker and S Sosath (Krebsforschungszentrum, Heidelberg) for supplying us with samples of honey and pollen from the different Euphorbiaceae.

Résumé - Étude en microscopie électronique à balayage du pollen du miel. IV. Sculpture de I'exine des pollens de diverses espèces d'Euphorbiacées. De nombreuses plantes de la famille des Euphorbiacées produisent des quantités considérables de nectar, que les abeilles utilisent pour le miel. L'existence des "miels de noors" ayant un fort pourcentage de nectar d'Euphorbia et de Sapium nous a permis de rechercher des moyens d'identification de ces pollens, afin de déterminer sans ambiguïté l'origine botanique des miels. Pour ce faire, des échantillons de pollen d'Euphorbia coerulescens, E ledienii, E tetragona et Sapium sebiferum ont été observés en microscopie optique et en microscopie électronique à balayage (MEB). L'analyse en microscopie optique n'a permis aucune différenciation : les pollens d'Euphorbia aussi bien que de Sapium sont tricolporés, avec une marge, et montrent en vue polaire le contour typique du cytoplasme (fig 1). II n'est pas possible de mettre en évidence des différences 
dans la structure de l'exine en raison de la faible profondeur de champ du microscope optique. Pour les études au MEB, on a fait passer des pollens en état de contraction à l'état d'expansion, en les mettant dans du miel filtré. Après les avoir isolés, on les a transférés sur un crible métallique (Dustmann et Bote, 1985).

Tous les pollens étudiés ont montré une structure de l'exine tecto-perforée. Quatre types de structures ont été trouvés : type $A$ (fig 2a, b; 3a, b), type B (fig 2c, d; 3c, d), type C (fig $2 \mathrm{e}, \mathrm{f} ; 3 \mathrm{e}, \mathrm{f}$ ) et type D (fig $2 \mathrm{~g}$, h; $3 g, h)$. Les sculptures se différencient par la disposition et la taille des perforations et par l'architecture des muri. Les types A, B et $C$ se rencontrent chez toutes les espèces d'Euphorbia et ne permettent donc pas de différencier les 3 espèces coerules cens, ledienii et tetragona. Par contre Sapium sebiferum présente une sculpture spécifique et une uniformité de la structure de l'exine (type D) qui, par ses muri extrêmement larges et plats, se distingue de tous les autres types. II est donc possible de différencier les miels d'Euphorbia de ceux de Sapium sebiferum.

pollen / miel / Euphorbiacea / microscopie optique / microscopie électronique à balayage

\section{Zusammenfassung - Raster-} elektronen-mikroskopische Studien an Pollen aus Bienenhonig. IV. Oberflächenmuster von Pollen aus verschiedenen Euphorbiaceae Arten. Zahlreiche Pflanzen aus der Familie der Euphorbiaceae produzieren beträchtliche Mengen an Nektar, der von Honigbienen eingetragen wird. Das Auftreten sog "Noors-Honige" mit hohen Anteilen an Euphorbia- und Sapium-Nektar veranlaßte uns, eine Möglichkeit zu finden, diese Pollen zu identifizieren, um die botanische Herkunft der Honige sicherzustellen.
Hierzu wurden authentische Pollenproben von Euphorbia coerulescens, E ledienii, E tetragona und Sapium sebiferum sowohl mit dem Lichtmikroskop als auch mit dem Raster-Elektronenmikroskop (REM) untersucht. Lichtmikroskopische Analysen ermöglichten keine Differenzierung: Sowohl Euphorbia- als auch SapiumPollen sind tricolporat, marginat und zeigen in der Pollage die typische Kontur des Plasmas (Abb 1). Unterscheidungen der Exine-Struktur waren aufgrund der geringen Tiefenschärfe des Lichtmikroskopes nicht möglich. Für die REMUntersuchungen wurden kontrahierte Pollen zur Expansion in pollenfreien Honig überführt und nach Isolierung in ein Edelstahlnetz präpariert (Dustmann und Bote, 1985). Alle untersuchten Pollen zeigen eine tectat-perforate Exine-Struktur. Insgesamt wurden 4 verschiedene StrukturTypen gefunden: Typ A (Abb 2a, b; 3a, b), Typ B (Abb 2c, d; 3c, d), Typ C (Abb 2e, f; $3 e, f)$ und Typ D (Abb 2g, h; 3g, h). Die Oberflächenmuster unterscheiden sich in Anordnung und Größe der Perforationen sowie im Aufbau der Muri. Typ A, B und C treten bei allen Euphorbia-Arten auf und lassen somit eine Differenzierung von $E$ coerulescens, $E$ ledienii, und $E$ tetragona nicht zu.

Sapium sebiferum zeigt jedoch ein spezifisches Muster und eine einheitliche Exine-Struktur (Typ D), die sich aufgrund der extrem breiten, flachen Muri von allen anderen Typen absetzt.

Die Ergebnisse zeigen, daß mit Hilfe des Raster-Elektronenmikroskopes die hier untersuchten Pollen der Gattung Euphorbia nicht untereinander aber von Sapium sebiferum unterschieden werden können und somit eine Differenzierung der entsprechenden Honige möglich ist.

Pollen / Honig / Euphorbiaceae / Lichtmikroskopie / Raster-Elektronenmikroskopie 


\section{REFERENCES}

Blackmore S, Barnes SH (1985) Harmomegathic mechanisms in pollen grains. In: Pollen and Spores: Form and Function: No 12 (Blackmore S, Ferguson IK, eds), London 173-149

Dustmann JH, Bote K (1985) Raster-elektronenmikroskopische Studien an Pollen aus Bienenhonig. I. Vergleich verschiedener Präparationsmethoden. Apidologie 16 (3), 331-340

Dustmann JH, Bote K (1987) Raster-elektronenmikroskopische Studien an Pollen aus Bienenhonig. II. Vergleich der Exine-Strukturen trockener und in Honig expandierter Pollen bei verschiedenen Apfel- bzw. Zierapfelsorten. Gartenbauwissenschaft 52, 271-278

Erdtman G (1952) Pollen Morphology and Plant Taxonomy. Angiosperms. Almquist and Wiksells, Uppsala, $539 \mathrm{pp}$

Erdtman G (1960) The acetolysis method. Svensk Bot Tidsskr 54 (4), 561-564

Faegri K, Iversen J (1964) Textbook of Pollen Analysis. Munksgaard, Copenhagen, $237 \mathrm{pp}$

Heywood VH (1982) Blütenpflanzen der Welt. Birkhäuser Verlag, Basel, $335 \mathrm{pp}$

Louveaux J, Maurizio A, Vorwohl G (1970) Internationale Kommission für Bienenbotanik der IUBS - Methodik der Melissopalynologie. Apidologie 1 (2), 193-209

Louveaux J, Maurizio A, Vorwohl G (1978) Methods of melissopalynology. Bee World 59 (4), 139-157

Sosath S, Ott HH, Hecker E (1988) Irritant principles of the spurge family (Euphorbiaceae) XIII. Oligocyclic and macrocyclic diterpene esters from lattices of some Euphorbia species utilized as source plants of honey. $J$ Nat Prod 51, 1062-1074

Ohe K von der, Dustmann JH (1990) Rasterelektronenmikroskopische Studien an Pollen aus Bienenhonig. III. Der HarmomegathieMechanismus und seine Auswirkungen auf die Exine-Strukturen am Beispiel unterschiedlicher Pollentypen. Apidologie 21, 293302

Ohe K von der (1991) Scanning electron microscopic studies of pollen from apple varieties. 6th Pollination Symposium. Acta Hortic 405409

Zander E (1935) Beiträge zur Herkunftsbestimmung bei Honig. I. Pollengestaltung und Herkunftsbestimmung bei Blütenhonig. Verlag der Reichsfachgruppe Imker eV, Berlin

Zander E (1941) Beiträge zur Herkunftsbestimmung bei Honig. III. Pollengestaltung und Herkunftsbestimmung bei Blütenhonig. Verlag Liedloff, Loth und Michaelis, Leipzig 